\title{
Dendritic Cell-Based Immunotherapy of Acute Myeloid Leukemia
}

\author{
Heleen H. Van Acker ${ }^{1}$, Maarten Versteven ${ }^{1}$, Felix S. Lichtenegger ${ }^{2}{ }^{(0}$, Gils Roex ${ }^{1}{ }^{1}$, \\ Diana Campillo-Davo ${ }^{1}$, Eva Lion $\left.{ }^{1}{ }^{(}\right)$, Marion Subklewe ${ }^{2}{ }^{\circledR}$, Viggo F. Van Tendeloo ${ }^{1}{ }^{(}$, \\ Zwi N. Berneman ${ }^{1,3}$ and Sébastien Anguille ${ }^{1,3, *}$ \\ 1 Laboratory of Experimental Hematology, Vaccine \& Infectious Disease Institute, Faculty of Medicine \& \\ Health Sciences, University of Antwerp, 2610 Wilrijk, Antwerp, Belgium; \\ heleen.vanacker@uantwerpen.be (H.H.V.A.); maarten.versteven@uantwerpen.be (M.V.); \\ gils.roex@uantwerpen.be (G.R.); Diana.CampilloDavo@uantwerpen.be (D.C.-D.); eva.lion@uza.be (E.L.); \\ vigske@gmail.com (V.F.V.T.); zwi.berneman@uza.be (Z.N.B.) \\ 2 Department of Medicine III, LMU Munich, University Hospital, 80799 Munich, Germany; \\ F.Lichtenegger@gmx.de (F.S.L.); Marion.Subklewe@med.uni-muenchen.de (M.S.) \\ 3 Division of Hematology and Center for Cell Therapy \& Regenerative Medicine, Antwerp University \\ Hospital, 2650 Edegem, Antwerp, Belgium \\ * Correspondence: sebastien.anguille@uza.be; Tel.: +32-3-821-56-96
}

Received: 21 March 2019; Accepted: 24 April 2019; Published: 27 April 2019

\begin{abstract}
Acute myeloid leukemia (AML) is a type of blood cancer characterized by the uncontrolled clonal proliferation of myeloid hematopoietic progenitor cells in the bone marrow. The outcome of AML is poor, with five-year overall survival rates of less than $10 \%$ for the predominant group of patients older than 65 years. One of the main reasons for this poor outcome is that the majority of AML patients will relapse, even after they have attained complete remission by chemotherapy. Chemotherapy, supplemented with allogeneic hematopoietic stem cell transplantation in patients at high risk of relapse, is still the cornerstone of current AML treatment. Both therapies are, however, associated with significant morbidity and mortality. These observations illustrate the need for more effective and less toxic treatment options, especially in elderly AML and have fostered the development of novel immune-based strategies to treat AML. One of these strategies involves the use of a special type of immune cells, the dendritic cells (DCs). As central orchestrators of the immune system, DCs are key to the induction of anti-leukemia immunity. In this review, we provide an update of the clinical experience that has been obtained so far with this form of immunotherapy in patients with AML.
\end{abstract}

Keywords: dendritic cells; immunotherapy; acute myeloid leukemia

\section{Introduction}

Acute myeloid leukemia (AML) is a highly aggressive type of leukemia characterized by the uncontrolled clonal proliferation of abnormal myeloid cells in the bone marrow [1-3]. AML primarily affects older people; over $50 \%$ of AML patients are older than 65 [1,2]. The past decades have witnessed an increased incidence of AML, which is mainly due to the aging population [4]. Treatment of AML remains challenging, although considerable advances have been made over the last 50 years. In this context, an influential discovery in the treatment of AML was the cytarabine-based chemotherapy in association with an anthracycline or related agent during the 1970s. This combination chemotherapy regimen significantly improved the probability to induce complete remission (CR) [5] and has consequently remained the backbone of frontline AML therapy [6]. The next major development 
in the treatment of AML was marked by the implementation of allogeneic hematopoietic stem cell transplantation (HSCT), which transformed this disease into a potentially curable one [7].

Despite these accomplishments, the long-term outcome of adults with AML remains precarious, with a five-year overall survival (OS) rate hovering at around 25\% [8]. According to data from the Surveillance, Epidemiology, and End Results (SEER) Program of the National Cancer Institute (NCI, Bethesda, MD, USA), the steady improvement in long-term survival since the mid-1970s is almost completely attributable to the decrease in mortality among patients younger than 65 years. By contrast, the prognosis of patients aged 65 years or older has not improved considerably over time, the latest reported five-year survival rate being $<10 \%$ [8]. Considering the above observation that elderly patients represent a significant and rising proportion of AML patients [4], one cannot but conclude that the overall picture remains grim, and that the scientific and therapeutic progress made did not translate into an equivalent improvement in long-term survival [2].

Perhaps the most important reason for this unsatisfying outcome is the high relapse-rate in leukemia, especially in elderly AML patients. Indeed, up to $80 \%$ of the patients older than 60 years will eventually relapse, despite having initially achieved $C R$ with conventional (poly)chemotherapy $[9,10]$. It is generally accepted that this relapse arises from the existence of a small reservoir of treatment-resistant leukemic (stem) cells (LSCs) that persist after chemotherapy [11], a condition known as minimal residual disease (MRD), which may evolve to a full clinical relapse [12,13]. Allogeneic HSCT can be used effectively to clear MRD and has a positive impact on relapse rate and survival. Unfortunately, HSCT is still associated with significant morbidity and mortality, generally limiting its use to younger patients with fewer co-morbidities [2]. For patients with no transplant donor available or for older patients who are usually deemed unfit for HSCT, there is currently no standard post-remission therapy to control MRD and avoid relapse [1,4,6,14].

The above observations emphasize the need for more effective and less aggressive treatment alternatives to improve the long-term outcome of $\mathrm{AML}$, especially in elderly patients. It is within this context that immunotherapy has come to the fore in recent years [12,15-17]. From the experience with allogeneic HSCT, we have learned that immune cells are indeed capable of recognizing and eliminating AML cells—-the so-called "graft-versus-leukemia" (GvL) effect [12,16]. Leukemia antigen-specific $\mathrm{CD}^{+}$cytotoxic T-lymphocytes (CTLs) and natural killer (NK) cells are the main immune effector cells responsible for attacking and killing AML cells (Figure 1) [12]. As conductors of the immunological orchestra, dendritic cells (DCs) are endowed with the potent and unique ability to harness the anti-leukemia activity of both immune effector cell types. It is therefore not surprising that DCs have attracted much interest in recent years as tools for immunotherapy of AML [12,18,19]. In this review, we summarize the clinical experience that has been obtained with this form of immunotherapy in AML.

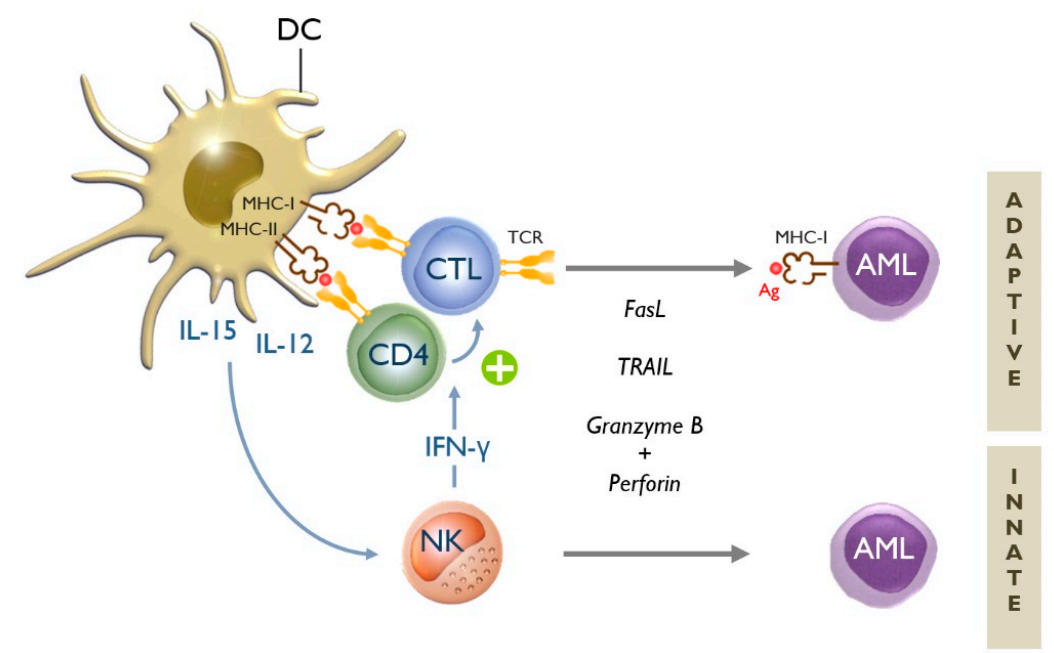

Figure 1. Dendritic cells are key to the induction of adaptive and innate anti-leukemia immunity. Dendritic 
cells (DCs) can stimulate both adaptive and innate immune responses against acute myeloid leukemia (AML) cells [12]. There exist two types of adaptive immune responses: humoral or B-cell-mediated (not shown in this figure), and cellular or T-cell-mediated immune responses. The initiation of the latter type of immune response involves the presentation of AML-related antigens (Ag) by DCs via major histocompatibility complex (MHC) class I and II molecules to $\mathrm{CD}^{+}$cytotoxic T-lymphocytes (CTLs) and $\mathrm{CD}^{+}$helper $\mathrm{T}$ cells, respectively. If appropriately stimulated, naive $\mathrm{CD} 4^{+} \mathrm{T}$ cells $\left(\mathrm{T}_{\mathrm{H}} 0\right)$ can be polarized into Thelper type $1\left(\mathrm{~T}_{\mathrm{H}} 1\right)$ cells, which in turn support the generation of antigen-specific CTLs (+). These CTLs_-via their specific T-cell receptor (TCR)-are capable of recognizing AML cells that display the particular antigen(s) to which the CTLs are directed [12]. CTLs possess different tools in their armamentarium to kill AML cells, such as death receptor ligands (e.g., Fas ligand (FasL) and tumor necrosis factor-related apoptosis-inducing ligand (TRAIL)) and cytolytic proteins released from intracytoplasmic granules (e.g., granzyme B and perforin) [16]. The innate arm of the immune system is unequivocally important for mounting effective anti-leukemia immunity [20]. Innate effector cells, predominantly natural killer (NK) cells, are able to eradicate AML cells in a non-antigen-specific, non-MHC-restricted manner. NK cells can utilize the same cytolytic tools as CTLs [16]. In addition to their direct cytotoxic activity, NK cells also play an immunoregulatory role by secreting cytokines such as interferon (IFN)- $\gamma$. Through this so-called "helper" function, NK cells can support the generation of $\mathrm{T}_{\mathrm{H}} 1$ and CTL responses [21,22]. Several DC-derived cytokines are known to be involved in DC-mediated NK-cell activation, including interleukin (IL)-12 and IL-15 [23]. The latter is usually not secreted by the DCs, but "trans-presented" on the DC surface via IL-15 receptor- $\alpha[24,25]$.

\section{Clinical Use of DCs for Immunotherapy of AML}

The feasibility, safety/toxicity and immunogenicity of DC vaccination in AML has been reviewed elsewhere (see Ref. [26]) and are outside the scope of this review. In addition, our group has previously done a cost-benefit analysis and found that DC therapy following chemotherapy is a cost-effective treatment [27]. Tables 1-3 provide an overview of all DC-based clinical studies performed so far in AML. As of 31 December 2018, nearly 200 patients with AML have been treated with this form of immunotherapy.

As shown in Tables 1-3 most studies have relied on DCs derived from autologous peripheral blood monocytes (moDCs), although allogeneic DCs have also been used [26]. In some studies, autologous leukemic blast cells were used as precursor cells for DC generation (AML-DCs) [26]. In one clinical trial, AML-DCs were generated from a leukemic cell line [28]. One drawback of the use of AML-DCs is their limited yield compared to moDCs, making clinical implementations more cumbersome [29]. In addition, in a head-to-head comparison between AML-DCs and moDCs, Draube and colleagues [29] found that moDCs were more effective in activating autologous leukemia-specific T cells than AML-DCs. Several arguments exist that could explain these findings. It has been postulated that AML-DCs lack the expression of 4-1BBL, an important ligand for co-stimulation [30]. Alternatively, indoleamine 2,3-dioxygenase 1 (IDO-1) expression by leukemic blasts can result in DCs with a more tolerogenic functionality [31]. Combined, these findings provide a preference of the use of moDCs over AML-DCs. On the other hand, AML-DCs have the advantage over moDCs in the sense that they present the full antigen repertoire of the leukemic blasts from which they are derived, thereby obviating the need for an antigen-loading step [26]. MoDCs, by contrast, require to be loaded with one or more AML antigens. This can be done by exogenous pulsing with a peptide (e.g., Wilms' tumor 1 [WT1] peptide) [32-36], by pulsing with apoptotic AML cells or lysates [37-40], by fusing the DCs with leukemic blasts (so-called fusion hybrids) [41,42], or by messenger RNA (mRNA) electroporation [8,43-45]. Messenger RNA electroporation involves the application of a brief electrical pulse to make the DC plasma membrane transiently permeable allowing the antigen-encoding mRNA to enter the cytosol. The mRNA will then be translated by the DCs into full-length antigenic protein. The translated antigen is further degraded into small peptide fragments, which are presented on the DC surface via major histocompatibility complex (MHC) molecules to the T cells. This technique has been used to load moDCs with one of the following leukemia-associated antigens: WT1, human telomerase reverse transcriptase (hTERT) 
and preferentially expressed antigen in melanoma (PRAME) [8,43-45]. mRNA electroporation is a non-viral gene transfer method; only one study implemented an (adeno)viral transduction approach for gene transfer of the leukemia-associated antigens survivin and MUC1 [46].

Table 1. Overview of DC (dendric cell) vaccine studies for AML (acute myeloid leukemia) in the post-HSCT setting.

\begin{tabular}{|c|c|c|c|c|}
\hline & $\begin{array}{l}\text { DC Type } \\
\text { (Auto/Allo) }\end{array}$ & $\begin{array}{l}\text { Antigen } \\
\text { (Loading) }\end{array}$ & Immunological Effects & Clinical Effects \\
\hline$n=1[37]$ & $\begin{array}{l}\mathrm{CD} 34^{+} \mathrm{DCs} \\
\text { (allogeneic) }\end{array}$ & $\begin{array}{l}\text { Apo-AML cells } \\
\text { (pulsing) }\end{array}$ & $\begin{array}{c}\text { Positive DTH } \\
\uparrow \text { T-cell reactivity to DCs }\end{array}$ & $\begin{array}{l}\downarrow \text { AML cell load } \\
\text { (morphological) }\end{array}$ \\
\hline$n=1[32]$ & $\begin{array}{c}\text { moDCs } \\
\text { (allogeneic) }\end{array}$ & $\begin{array}{l}\mathrm{WT}_{235} \\
\text { (pulsing) }\end{array}$ & $\begin{array}{c}\text { Positive DTH } \\
\leftrightarrow \text { WT1-specific T cells }\end{array}$ & Absent \\
\hline$n=1[47]$ & $\begin{array}{l}\text { MoDCs* } \\
\text { (allogeneic) }\end{array}$ & Unloaded & Allo-MLR response to DCs & Absent \\
\hline$n=1[34]$ & $\begin{array}{c}\text { moDCs } \\
\text { (allogeneic) }\end{array}$ & $\begin{array}{l}\text { WT1 } 1_{37 ; 126 ; 187} \\
\text { (pulsing) }\end{array}$ & Absence of WT1 response & Absent \\
\hline$n=2[38]$ & $\begin{array}{c}\text { moDCs } \\
\text { (autologous) }\end{array}$ & $\begin{array}{l}\text { AML cell lysate } \\
\text { (pulsing) }\end{array}$ & $\begin{array}{c}\text { Positive DTH } \\
\uparrow \text { T-cell reactivity to DCs }\end{array}$ & Absent \\
\hline$n=19 / 23[46]$ & $\begin{array}{l}\text { MoDCs ** } \\
\text { (autologous) }\end{array}$ & $\begin{array}{l}\text { survivin/MUC1 } \\
\text { (adenovirus) }\end{array}$ & ND & $\begin{array}{c}\text { Induction of CR (13) } \\
\text { Favorable OS ( } 48.9 \% \text { at } 3 \text { years) }\end{array}$ \\
\hline$n=12[46]$ & $\begin{array}{l}\text { MoDCs ** } \\
\text { (autologous) }\end{array}$ & $\begin{array}{l}\text { survivin/MUC1 } \\
\text { (adenovirus) }\end{array}$ & ND & Induction of CR (10) \\
\hline
\end{tabular}

Abbreviations: HSCT, hematopoietic stem cell transplantation; $n$, number of DC-treated patients; DC type, type of DC used; auto, DCs from autologous origin; allo, DCs from allogeneic origin; CD34 ${ }^{+}$DCs, DCs derived from CD34 ${ }^{+}$ hematopoietic progenitor cells; moDCs, monocyte-derived DCs; ${ }^{*}$, in combination with donor lymphocyte infusions (DLI); **, in combination with cytokine-induced killer cells; Antigen, antigenic material used to load DCs; loading, antigen-loading method used; Apo-AML cells, apoptotic AML cells; WT1 137126;187;235, designated epitope derived from Wilms' tumor 1 (WT1) antigen; MUC1, mucin 1; DTH, delayed-type hypersensitivity test; $\uparrow$, increase; $\leftrightarrow$, steady state; allo-MLR, allogeneic mixed lymphocyte reaction; ND, no data; $\downarrow$, decrease; $C R$, complete remission; (number), number of patients in whom the designated clinical effect was observed; OS, overall survival.

Table 2. Overview of DC vaccine studies for AML in an advanced disease setting.

\begin{tabular}{|c|c|c|c|c|}
\hline & $\begin{array}{l}\text { DC Type } \\
\text { (Auto/Allo) }\end{array}$ & $\begin{array}{c}\text { Antigen } \\
\text { (Loading) }\end{array}$ & Immunological Effects & Clinical Effects \\
\hline$n=1[41]$ & $\begin{array}{c}\text { moDCs } \\
\text { (allogeneic) }\end{array}$ & $\begin{array}{l}\text { AML cells } \\
\text { (fusion } \\
\text { hybrids) }\end{array}$ & ND & Disease stabilization \\
\hline$n=4[39]$ & $\begin{array}{c}\text { moDCs } \| \\
\text { (autologous) }\end{array}$ & $\begin{array}{l}\text { Apo-AML cells } \\
\text { (pulsing) }\end{array}$ & $\begin{array}{c}\uparrow \text { AML-reactive T cells (2/4) } \\
\uparrow \text { WT1/hTERT-specific T cells (1/1) }\end{array}$ & Disease stabilization (2/4) \\
\hline$n=5[48]$ & $\begin{array}{l}\text { AML-DCs } \\
\text { (autologous) }\end{array}$ & $\mathrm{NA}$ & $\begin{array}{c}\uparrow \text { PRAME-specific T cells (1/3) } \\
\uparrow \text { IFN- } \gamma \text { by CD4 } 4^{+} \mathrm{T} \text { cells }(2 / 3) \\
\mathrm{T}_{\mathrm{H}} 1 / \mathrm{T}_{\mathrm{H}} 2 \text { cytokine profile }\end{array}$ & $\begin{array}{l}\text { Disease stabilization (1) } \\
\downarrow \text { AML cell load (2) } \\
\text { (morphological) }\end{array}$ \\
\hline$n=8+[35,36]$ & $\begin{array}{c}\text { moDCs } \| \\
\text { (autologous) }\end{array}$ & $\begin{array}{l}\text { WT1 peptide } \\
\text { (pulsing) }\end{array}$ & $\begin{array}{l}\uparrow \text { WT1-specific T cells } \\
\text { (in clinical responders) } \\
\downarrow T_{\text {reg cells and MDSCs }} \\
\text { (in clinical responders) }\end{array}$ & $\begin{array}{l}\text { Disease stabilization (3) } \\
\downarrow \text { AML cell load (2) } \\
\text { (molecular) }\end{array}$ \\
\hline$n=21[49]$ & $\begin{array}{l}\text { AML-DCs } * * \\
\text { (autologous) }\end{array}$ & $\mathrm{NA}$ & $\begin{array}{c}\uparrow \mathrm{CD}^{+} \text {and } \mathrm{CD} 8^{+} \mathrm{T} \text { cells } \\
\uparrow \mathrm{T}_{\mathrm{H}} 1 \text { cytokines }\end{array}$ & $\begin{array}{l}\text { Induction of CR (6) } \\
\text { Induction of PR (9) }\end{array}$ \\
\hline
\end{tabular}

Abbreviations: $n$, number of DC-treated patients; $\mathrm{t}$, including two patients with acute lymphoblastic leukemia (ALL); DC type, type of DC used; auto, DCs from autologous origin; allo, DCs from allogeneic origin; moDCs, monocyte-derived DCs; $\|$, in combination with systemic administration of the Toll-like receptor agonist OK432; AML-DCs, AML cell-derived DCs; ${ }^{* *}$, in combination with cytokine-induced killer cells and low-dose chemotherapy (for further details, see [49]); Antigen, antigenic material used to load DCs; loading, antigen-loading method used; Apo-AML cells, apoptotic AML cells; NA, not applicable; WT1, Wilms' tumor 1 antigen; ND, no data; $\uparrow$, increase; hTERT, human telomerase reverse transcriptase; PRAME, preferentially expressed antigen in melanoma; IFN-, interferon; $\mathrm{T}_{\mathrm{H}} 1 / \mathrm{T}_{\mathrm{H}} 2$, T helper type 1 or $2 ; \downarrow$, decrease; $\mathrm{T}_{\mathrm{reg}}$, regulatory $\mathrm{T}$ cells; MDSCs, myeloid-derived suppressor cells; CR, complete remission; PR, partial remission; (number), number of patients in whom the designated immunological or clinical effect was observed. 
Table 3. Overview of DC vaccine studies for AML in a post-remission setting.

\begin{tabular}{|c|c|c|c|c|}
\hline & $\begin{array}{l}\text { DC Type } \\
\text { (Auto/Allo) }\end{array}$ & $\begin{array}{l}\text { Antigen } \\
\text { (Loading) }\end{array}$ & Immunological Effects & Clinical Effects \\
\hline$n=3[33]$ & $\begin{array}{c}\text { moDCs } \diamond \\
\text { (autologous) }\end{array}$ & $\begin{array}{l}\text { WT1 } 1_{235} \\
\text { (pulsing) }\end{array}$ & $\begin{array}{c}\text { Positive DTH (2/3) } \\
\uparrow \text { WT1-specific T cells (2/2) } \\
\text { No } \uparrow \gamma \delta \text { T cells }\end{array}$ & $\begin{array}{c}\text { Disease stabilization (1/3) } \\
\downarrow \text { AML cell load (1/3) } \\
\text { (morphological) }\end{array}$ \\
\hline$n=5[43,50]$ & $\begin{array}{c}\text { moDCs } \\
\text { (autologous) }\end{array}$ & $\begin{array}{l}\text { WT1/PRAME } \\
\text { (mRNA EP) }\end{array}$ & $\begin{array}{c}\text { Positive DTH (4) } \\
\uparrow \text { Ag-specific T cells (2) }\end{array}$ & Continued CR $(21,25,33 \mathrm{~m})(3)$ \\
\hline$n=5[51]$ & $\begin{array}{l}\text { AML-DCs } \\
\text { (autologous) }\end{array}$ & NA & $\begin{array}{c}\text { Minimal or absent DTH } \\
\uparrow \text { AML-reactive T cells (4/4) } \\
\uparrow \mathrm{WT} 1 \text {-specific T cells }(1 / 1) \\
\text { No } \uparrow \mathrm{T}_{\text {reg cells }}\end{array}$ & Continued CR (13-16 m) (2) \\
\hline$n=5[40]$ & $\begin{array}{c}\text { moDCs } \\
\text { (autologous) }\end{array}$ & $\begin{array}{l}\text { Apo-AML cells } \\
\text { (pulsing) }\end{array}$ & ND & Continued CR (+13 m) (1) \\
\hline$n=12[28]$ & $\begin{array}{l}\text { AML-DCs } \\
\text { (allogeneic) }\end{array}$ & NA & $\begin{array}{c}\text { Positive DTH } \\
\uparrow \text { WT1/PRAME-specific T cells }\end{array}$ & $\begin{array}{l}\text { Disease stabilization (1) } \\
\text { Disease stabilization (1) } \\
\text { Favorable OS in patients } \\
\text { without circulating blasts }\end{array}$ \\
\hline$n=10 / 13[44]$ & $\begin{array}{c}\text { moDCs } \\
\text { (autologous) }\end{array}$ & $\begin{array}{l}\text { WT1/PRAME/ } \\
\text { CMVpp65 } \\
\text { (mRNA EP) }\end{array}$ & $\begin{array}{c}\text { Local immune response (10) } \\
\uparrow \text { Ag-specific T cells WT1 (2/10) } \\
\text { PRAME }(4 / 10) \\
\text { CMV }(9 / 10)\end{array}$ & $\begin{array}{l}\text { Favorable RFS (1084 days vs. } \\
396 \text { days in matched cohort) } \\
\text { Prolonged RFS and OS in } \\
\text { immune responders }\end{array}$ \\
\hline$n=17[42]$ & $\begin{array}{c}\text { moDCs } \\
\text { (autologous) }\end{array}$ & $\begin{array}{c}\text { AML cells } \\
\text { (fusion hybrids) }\end{array}$ & $\begin{array}{l}\uparrow \text { AML-reactive T cells (6) } \\
\uparrow \text { AML Ag-specific T cells (2) } \\
\text { (i.e., MUC1, WT1 or PRAME) }\end{array}$ & Favorable RFS (71\% at $57 \mathrm{~m})$ \\
\hline$n=21[45]$ & $\begin{array}{c}\text { moDCs } \\
\text { (autologous) }\end{array}$ & $\begin{array}{c}\text { hTERT } \\
\text { (mRNA EP) }\end{array}$ & $\begin{array}{c}\text { Positive DTH } \\
\uparrow \text { hTERT-specfic T cells (11/19) }\end{array}$ & Favorable RFS (58\% at $52 \mathrm{~m}$ ) \\
\hline$n=30[8,52]$ & $\begin{array}{c}\text { moDCs } \\
\text { (autologous) }\end{array}$ & $\begin{array}{c}\text { WT1 } \\
\text { (mRNA EP) }\end{array}$ & $\begin{array}{c}\text { Positive DTH } \\
\uparrow \text { WT1-specific T cells } \\
\text { (in clinical responders) } \\
\text { NK activation }(4 / 10)\end{array}$ & $\begin{array}{c}\text { Induction of CMR (9) } \\
\text { Disease stabilization (4) } \\
\text { Favorable RFS in responders } \\
\text { Favorable OS }\end{array}$ \\
\hline
\end{tabular}

Abbreviations: $n$, number of DC-treated patients; DC type, type of DC used; auto, DCs from autologous origin; allo, DCs from allogeneic origin; moDCs, monocyte-derived DCs; $\diamond$, pulsed with zoledronic acid in an attempt to induce $\gamma \delta$ T-cell anti-leukemia immunity; AML-DCs, AML cell-derived DCs; Antigen, antigenic material used to load DCs; loading, antigen-loading method used; $\mathrm{WT}_{235}$, designated epitope derived from Wilms' tumor 1 (WT1) antigen; PRAME, preferentially expressed antigen in melanoma; mRNA EP, messenger RNA electroporation; NA, not applicable; Apo-AML cells, apoptotic AML cells; CMVpp65, Cytomegalovirus pp65 peptide; hTERT, human telomerase reverse transcriptase; DTH, delayed-type hypersensitivity test; $\uparrow$, increase; Ag, antigen; $\mathrm{T}_{\text {reg }}$, regulatory T cells; ND, no data; MUC1, mucin 1; NK, natural killer cell; $\downarrow$, decrease; CR, complete remission; CMR, complete molecular remission; RFS, relapse-free survival; OS, overall survival; (number), number of patients in whom the designated immunological or clinical effect was observed; (number m), follow-up time in months.

Non-specific and antigen-specific immunological effects have been obtained in a considerable number of DC-treated AML patients. These effects include delayed-type hypersensitivity (DTH) skin test reactions, which essentially confirms the ability of the DCs to elicit T-cell-mediated immunity in vivo [52]. Other (non-specific) signs of the immunogenicity of DC therapy that have been observed include: increases in $\mathrm{CD}^{+}$and/or $\mathrm{CD}^{+}$T-cell frequencies during or after DC administration [49,53], enhanced activation of $\mathrm{CD}^{+}{ }^{+}$cells, as evidenced by their increased IFN- $\gamma$ production following DC therapy [48], and elevations in plasma levels of immunostimulatory or $\mathrm{T}_{\mathrm{H}}$ 1-polarizing cytokines (such as interleukin (IL)-2) $[48,49,52]$. Regarding the increased IFN- $\gamma$ expression, it should be mentioned that IFN- $\gamma$ can in turn have an effect on DCs. It is known that IFN- $\gamma$ can induce IDO expression in subsets of DCs [54] and that this can induce tolerance in the DCs under specific circumstances. This might serve as an explanation why IDO-1 expression correlates with poor clinical outcome in patients with AML [55-57]. To date, studies have focused on the effects of IDO-expression in AML-blasts. Therefore, during the generation of AML-DCs derived from AML-blasts, their IDO-1 expression status might need to be taken into consideration. In contrast, the effect of IDO-expression on the phenotype and function of moDCs has not been studied yet. Several studies listed in Tables 1-3 have provided proof-of-principle that antigen-loaded DCs can induce leukemia antigen-specific T-cell immunity in patients with AML. 
Specific T-cell responses have been demonstrated by direct ex vivo tetramer analysis and/or following in vitro antigenic restimulation experiments towards the following AML-related tumor antigens: WT1 [33,35,36,39,44,51-53,58,59], PRAME [44,48,53,59], hTERT [39,60,61], and MUC1 [59]. It was also shown that DC-induced T-cell immune responses within a single patient can be directed against multiple antigens (e.g., WT1 and PRAME [44,53], or WT1 and hTERT [39]) and/or multiple epitopes a particular antigen (e.g., WT1 $1_{37-45}, \mathrm{WT} 1_{126-134}, \mathrm{WT} 1_{187-195}$, and $\mathrm{WT}_{235-243}$ ) [52]. This ability to induce multi-antigen- or multi-epitope-specific T-cell immunity is important, as this reduces the likelihood of tumor escape from T-cell recognition due to antigen loss (i.e., loss of expression of a single antigen/epitope) [62] or antigenic drift (i.e., mutations leading to epitope changes resulting in failure of the CTLs to recognize the original epitope) [63]. Theoretically, the use of DCs loaded with multiple antigens or AML lysates could also involve a higher risk of autoimmunity, for example, towards non-malignant cells that also express low levels of leukemia-associated antigens [64]. In clinical trials, treatment with multiple antigen-loaded DCs are well tolerated, and no or minor autoimmune reactions are normally observed [38]. Several studies have shown that DC therapy can also elicit leukemia antigen-specific T cells in the bone marrow compartment $[39,59]$, which is of special importance in view of the observation that the bone marrow is the primary site where high-avidity AML-reactive CTLs reside [65].

In AML, DC vaccines have been applied in three different clinical settings: (a) in the context of HSCT, usually for treatment of relapsed AML after allogeneic HSCT (Table 1); (b) in an advanced disease setting, for example, for patients with refractory disease or relapsed AML for whom conventional treatment options have been exhausted (Table 2); and (c) after chemotherapy-induced remission of AML to prevent or delay relapse (Table 3). In the post-transplant relapse setting (Setting a), one study merits further discussion. Here, multi-genetically modified moDCs (Ad-siSSF DCs) were manufactured based on an adenovirus delivering: (i) secretory flagellin, a Toll-like receptor (TLR)-5 agonist inducing DC maturation; (ii) a survivin-MUC1 fusion protein, two leukemia-associated antigens; and (iii) SOCS1 shRNA, an RNA interference moiety overriding the intracellular immune checkpoint molecule SOCS1 [46]. Forty-eight patients with a post-transplant acute leukemia relapse (all AML, except for seven patients with acute lymphoblastic leukemia) were treated with either Ad-siSSF DCs or donor lymphocyte infusions (DLI). The vaccine was not only found to be safe but also induced a three-year OS of $48.9 \%$ compared with $27.5 \%$ in the DLI group. Thirteen out of $23(57 \%)$ patients treated with the Ad-siSSF DCs achieved CR versus 12 out of $25(48 \%)$ treated with DLI. In a second phase, 12 AML patients with early molecular relapse after HSCT were treated with Ad-siSSF DCs. Here, DC vaccination induced a CR rate of $83 \%$ (10 out of 12 patients). It should, however, be pointed out that the patients also received two subsequent infusions of cytokine-induced killer cells (CIKs), potentially contributing to the clinical effects of the DC vaccine. Moreover, all 12 patients were in early (molecular) relapse and efficacy would likely be lower in full-blown relapse $[66,67]$. This is supported by a mouse model of DC-based immunotherapy of AML [68], indicating that the therapeutic utility of DC vaccines is limited in the case of a high leukemic cell load.

In patients with relapsed/refractory AML (Setting $b$ ), clinical responses were usually limited to temporary disease stabilizations before further progression $[39,41,48]$ and/or transient reductions in leukemic cell load $[35,36,48]$. The latter was evidenced either morphologically by demonstration of decreases in blast counts [48], or molecularly by demonstration of decreases in WT1 tumor marker transcript levels (as measured by quantitative reverse-transcriptase polymerase chain reaction (qRT-PCR) [35,36]. WT1 is a transcription factor used as a molecular marker for the monitoring of minimal residual disease in leukemia, especially in myeloid leukemias and myelodysplastic syndrome [69]. It is also a predictive factor of imminent relapse in AML patients, including those that received allo-SCT, even when other markers are not available [70-73]. Only one study [49] reported $\mathrm{CR}$ and partial remissions (PR) in the relapsed/refractory setting. It is important to note, however, that these patients also received chemotherapy and CIKs, making it difficult to draw conclusions about the effectiveness of DCs as a stand-alone treatment for advanced AML. In patients with advanced AML, 
immunosuppressive cells ( $\mathrm{T}_{\text {reg }}$ cells and myeloid-derived suppressor cells (MDSCs)) may prevail over anti-tumor immune effector cells (CTLs and NK cells), explaining the higher likelihood of treatment failure when applying immunotherapy in the context of a high tumor burden $[67,74]$.

The most obvious proof of clinical activity of DC vaccination in monotherapy has indeed been gathered in patients with low disease burden or MRD (Setting c). The concept is to administer DC vaccines as consolidation therapy to prevent or postpone relapse. Sustained and longer than usual CRs were reported in all post-remission DC vaccine studies, but the single-arm design of these studies precludes drawing firm conclusions on the true efficacy with respect to relapse prevention $[28,40,43,44$, $50,51]$. Nevertheless, several clinical trials have reported exceptionally long progression-free survival (PFS) times $[42,44,45]$, indicating that DC vaccination can be an effective strategy to prevent/delay relapse. In the study by Rosenblatt et al. [42], 17 AML patients who achieved remission after chemotherapy, were vaccinated with moDCs fused to AML cells. This resulted in a $71 \%$ relapse-free survival at a median follow-up of 57 months. Moreover, the treatment was well tolerated and adverse events were transient and minor (grade 1-2 intensity). It should, however, be noted that the selection bias for long-term survivors requires careful interpretation of the data [42]. The achieved prevention of relapse is nonetheless remarkable when comparing to the treatment of patients aged 60-70 years with reduced intensity conditioning HSCT or chemotherapy alone resulting in three-year relapse-free survival of $68 \%$ and $19 \%$, respectively [75]. In a study by Khoury et al. [45], 22 intermediate- or high-risk AML patients (median age of 58 years) were treated with human telomerase reverse transcriptase (hTERT)-expressing DCs. Given the central role of telomerase activity in maintaining self-renewal of leukemic stem cells, hTERT-DC vaccination may be ideally suited to target the small reservoir of residual leukemic stem cells that persist after chemotherapy. hTERT-DC vaccines administered in the post-remission setting were well tolerated and, after 52 months, $58 \%$ of the patients were free of disease recurrence. This compares favorably to the reported three-year relapse rates of $60 \%$ and $90 \%$ for patients with intermediate- and high-risk AML, respectively [76].

The group of Dr Felix Lichtenegger and Prof Marion Subklewe from Munich, Germany, used TLR-7/8-matured DCs loaded with WT1, PRAME and CMVpp65 mRNA in 10 AML patients who were in remission after intensive chemotherapy, but at high risk of relapse. The vaccination proved to be safe and resulted in local inflammatory responses with dense T-cell infiltration. Increased antigen-specific $\mathrm{CD}^{+} \mathrm{T}$ cells were seen in peripheral blood for all three antigens. PFS was 1084 days, comparing favorably to a closely matched cohort from a patient registry of the same study group (Table 3). Median overall survival was not reached at the end of observation. In particular, excellent survival was seen in the immune responders (Ref. [44] and personal communication).

Our group has also shown that DC vaccination can confer an OS benefit in remission patients with AML. In a recently completed phase II clinical trial [8], we treated 30 AML patients with autologous, WT1 mRNA-electroporated moDCs following standard induction chemotherapy; 27 of them were in CR and three were in PR. Two out of these three patients in PR were brought into CR by DC therapy. Most patients did not have morphologically demonstrable disease prior to the start of DC therapy but had evidence of residual disease at the molecular level (i.e., elevated WT1 transcript levels in blood and/or marrow, as determined by qRT-PCR). In nine patients who had an increased level of the WT1 tumor marker at the start of DC therapy, WT1 transcript levels returned to normal during DC vaccination, compatible with the induction of complete molecular remission (CMR). Five of these nine patients are still in CMR now more than five years after diagnosis and can be probably considered as cured. Apart from induction of morphological and/or molecular remission, four patients experienced disease stabilization for a period of time, a situation that is highly uncommon in AML given the aggressive behavior of this disease. The objective clinical response rate was $43 \%$. PFS was significantly different in responders vs. non-responders. OS compared favorable to controls from the SEER and Swedish Acute Leukemia Registry, in patients $\leq 65$ as well as $>65$ years, and was linked to the induction of WT1-specific CD8 ${ }^{+}$T-cell immunity [8]. Eleven out of 30 patients were alive in CR with a median OS from diagnosis of eight years (range 72.6-125.5 months), at the time of publication. 
These encouraging results have led us to embark on a follow-up randomized clinical trial comparing WT1 mRNA-electroporated DC vaccination with standard-of-care in the post-remission setting of AML. The study is open for inclusion (Clinicaltrials.gov identifier NCT01686334).

\section{Conclusions and Future Perspectives}

Taken together, it can be concluded that DC-based immunotherapy has the potential to bring about demonstrable clinical responses in patients with AML. This holds particularly true in the post-remission setting of AML where treatment with DCs can produce durable remissions and prevent or delay relapse in some high-risk patients. Unfortunately, not all patients experience overt clinical benefit from this form of immunotherapy, underscoring the need to delve further into the possible reasons for therapeutic success or failure. In all studies listed in Tables 1-3 patients who failed to mount an immune response to DC vaccination had an inferior clinical outcome as compared to immune responders, indicating that the elicitation of (anti-leukemia) immunity by DCs is required to obtain a clinical response. For example, in our phase II clinical trial of WT1-targeted DC vaccination as a post-remission treatment for AML, only patients in whom DC vaccination elicited a poly-epitope WT1-specific CD8 ${ }^{+}$ T-cell immune response experienced sustained CR $[52,58]$. There was also evidence in our study for a correlation between DC-induced NK cell activation and clinical activity [52]. As becomes evident from the data summarized in Tables 1-3 there is also a considerable number of patients who do not mount a clinical response despite the presence of DC-induced immune changes. One possible explanation for this observation is that the DCs currently used for immunotherapy are too weakly immunogenic to evoke clinically beneficial immune responses and/or that they do not induce the "right" type of immunity, i.e.:

- The immunostimulatory activity of the DCs may be too weak to induce high-avidity, long-lived leukemia-specific CTLs capable of mediating cytotoxicity of AML cells [33,39].

- The immunostimulatory activity of the DCs may be too weak to activate NK cells or $\gamma \delta$ T-cells and harness innate immunity against AML cells [77-82].

- The immunostimulatory activity of the DCs may be too weak to overcome the immunosuppressive action of $\mathrm{T}_{\text {reg }}$ cells and MDSCs $[35,36,51,83]$.

- The DCs used for therapy may favor the induction of a $\mathrm{T}_{\mathrm{H}} 2$ response over a $\mathrm{T}_{\mathrm{H}} 1$ response [84,85], which is otherwise the type of immunity that would be preferred in the setting of cancer immunotherapy [48].

- The DCs used for therapy may favor immune tolerance and produce undesired immune effects such as induction of $\mathrm{T}_{\text {reg }}$ cells and MDSCs $[35,36,86]$.

These observations explain the impetus behind the many research efforts that are currently being undertaken to optimize the immunostimulatory properties of DCs in order to increase the likelihood of inducing protective anti-leukemia immunity in AML patients and, consequently, also the likelihood of therapeutic success [87]. One of the promising next-generation DC product candidates are IL-15-differentiated DCs [88]. In contrast to conventional IL-4 moDC vaccines, IL-15 DCs proved to be superior antigen-presenting cells, capable of direct tumoricidal activity [89], and, via expression of IL-15, capable of harnessing both NK cells and $\gamma \delta \mathrm{T}$ cells in the anti-tumor immune response [82,90].

Combining DC therapy with immune checkpoint targeting strategies, currently evoking a renaissance in the cancer immunotherapy field [91,92], is another avenue to unlock the full therapeutic potential of DC vaccines for AML. Moving beyond the combination of DC vaccines with systemic monoclonal antibodies, interceding programmed death (PD)-1/PD-L signaling in the DCs themselves reinforces the DC-mediated $\mathrm{T}$ cell and NK cell activation and prevents $\mathrm{T}_{\text {reg }}$ cell stimulation [91,92].

Another potential approach to enhance efficacy of DC therapy is combination with AML-specific monoclonal antibodies. Leukemia-specific mAb targets include CD33, CD123 and CD56, as reviewed in $[93,94]$. Especially ADCC-eliciting antibodies are interesting in the context of combination with DC vaccination, as ADCC-mediated killing results in the release of tumor neoantigens that can be taken up 
and cross-presented by tumor-residing DCs [95]. However, as of now, there are no studies combining such mAbs with DC therapy in AML.

Finally, there is an increasing interest to combine DC vaccination with conventional therapies, given the potential synergism between both. In our phase II clinical trial of WT1 mRNA-electroporated DC vaccination, we observed unexpectedly high second remission rates and OS times to subsequent salvage treatment (i.e., chemotherapy and/or allogeneic HSCT) in vaccinated patients that experienced the first relapse. This may indicate that DC vaccination can potentiate the response to subsequent treatment, an observation that has also been made in the solid tumor vaccine field $[67,96]$. Hypomethylating agents (HMAs), which are being increasingly applied in the frontline treatment of elderly AML patients, have also shown synergistic activity with DC vaccination; one of the mechanisms underlying this synergism involves reduction of PD-1 expression on T cells and inhibition of MDSCs [97]. A phase II randomized clinical trial (Clinicaltrials.gov identifier NCT01686334) is currently ongoing to evaluate the effectiveness of combined HMA treatment and WT1 mRNA-targeted DC vaccination.

Author Contributions: Conceptualization, H.H.V.A. and S.A.; Methodology, H.H.V.A., M.V., F.S.L., G.R., D.C.-D. and S.A.; Writing-Original Draft Preparation, H.H.V.A., M.V., F.S.L. and S.A.; Writing-Review and Editing, E.L., M.V., D.C.-D., M.S., V.F.V.T., Z.N.B. and S.A.; Visualization, S.A.; Supervision, E.L., M.S., V.F.V.T., Z.N.B. and S.A.; Project Administration, E.L.; and Funding Acquisition, E.L., V.F.V.T., Z.N.B. and S.A.

Funding: This work was supported by grants from the Fund for Scientific Research Flanders (FWO Vlaanderen, grants G.0535.18N and 1524919N), the Baillet-Latour Fund, Kom op Tegen Kanker (KoTK) and the Belgian Foundation against Cancer (Stichting tegen Kanker, grant 2016-138 FAF-C/2016/764). We also received support from a Methusalem Fund from the University of Antwerp, from the Kaushik Bhansali Fund, and from the Belgian public utility foundations VOCATIO and Horlait-Dapsens. H.H.V.A. held a Ph.D. fellowship of the FWO (grant 11ZL518N). MV holds a Doctoral Grant Strategic Basic Research of the FWO (grant 1S24517N). G.R. receives a doctoral scholarship from the University of Antwerp. D.C.D. is supported by a DOC-PRO Ph.D. grant of the Special Research Fund (BOF) of the University of Antwerp.

Conflicts of Interest: V.F.V.T. and Z.N.B. are co-inventors of a patent covering the messenger RNA electroporation technique (WO/2003/000907; improved transfection of eukaryotic cells with linear polynucleotides by electroporation). The remaining authors declare no competing financial interests.

\section{References}

1. Estey, E.; Doehner, H. Acute myeloid leukaemia. Lancet 2006, 368, 1894-1907. [CrossRef]

2. Ferrara, F.; Schiffer, C.A. Acute myeloid leukaemia in adults. Lancet 2013, 381, 484-495. [CrossRef]

3. De Veirman, K.; Van Valckenborgh, E.; Lahmar, Q.; Geeraerts, X.; De Bruyne, E.; Menu, E.; Van Riet, I.; Vanderkerken, K.; Van Ginderachter, J.A. Myeloid-derived suppressor cells as therapeutic target in hematological malignancies. Front. Oncol. 2014, 4, 349. [CrossRef] [PubMed]

4. Sekeres, M.A. Treatment of older adults with acute myeloid leukemia: state of the art and current perspectives. Haematologica 2008, 93, 1769-1772. [CrossRef] [PubMed]

5. Tallman, M.S.; Gilliland, D.G.; Rowe, J.M. Drug therapy for acute myeloid leukemia. Blood 2005, 106, 1154-1163. [CrossRef]

6. Rowe, J.M.; Tallman, M.S. How I treat acute myeloid leukemia. Blood 2010, 116, 3147-3156. [CrossRef]

7. Peccatori, J.; Ciceri, F. Allogeneic stem cell transplantation for acute myeloid leukemia. Haematologica 2010, 95, 857-859. [CrossRef]

8. Anguille, S.; Van de Velde, A.L.; Smits, E.L.; Van Tendeloo, V.F.; Juliusson, G.; Cools, N.; Nijs, G.; Stein, B.; Lion, E.; Van Driessche, A.; et al. Dendritic cell vaccination as postremission treatment to prevent or delay relapse in acute myeloid leukemia. Blood 2017, 130, 1713-1721. [CrossRef] [PubMed]

9. Buchner, T.; Berdel, W.E.; Haferlach, C.; Schnittger, S.; Haferlach, T.; Serve, H.; Mueller-Tidow, C.; Braess, J.; Spiekermann, K.; Kienast, J.; et al. Long-term results in patients with acute myeloid leukemia (AML): The influence of high-dose AraC, G-CSF priming, autologous transplantation, prolonged maintenance, age, history, cytogenetics, and mutation status. Data of the AMLCG 1999 trial. Blood 2009, 114, $200-201$.

10. Stone, R.M.; Berg, D.T.; George, S.L.; Dodge, R.K.; Paciucci, P.A.; Schulman, P.P.; Lee, E.J.; Moore, J.O.; Powell, B.L.; Baer, M.R.; et al. Postremission therapy in older patients with de novo acute myeloid leukemia: a randomized trial comparing mitoxantrone and intermediate-dose cytarabine with standard-dose cytarabine. Blood 2001, 98, 548-553. [CrossRef] 
11. Snauwaert, S.; Vandekerckhove, B.; Kerre, T. Can immunotherapy specifically target acute myeloid leukemic stem cells? Oncoimmunology 2013, 2, e22943. [CrossRef]

12. Schurch, C.M.; Riether, C.; Ochsenbein, A.F. Dendritic cell-based immunotherapy for myeloid leukemias. Front. Immunol. 2013, 4, 496. [CrossRef]

13. Hourigan, C.S.; Karp, J.E. Minimal residual disease in acute myeloid leukaemia. Nat. Rev. Clin. Oncol. 2013, 10, 460-471. [CrossRef] [PubMed]

14. Vasu, S.; Kohlschmidt, J.; Mrozek, K.; Eisfeld, A.K.; Nicolet, D.; Sterling, L.J.; Becker, H.; Metzeler, K.H.; Papaioannou, D.; Powell, B.L.; et al. Ten-year outcome of patients with acute myeloid leukemia not treated with allogeneic transplantation in first complete remission. Blood Adv. 2018, 2, 1645-1650. [CrossRef]

15. Smits, E.L.J.M.; Berneman, Z.N.; Van Tendeloo, V.F.I. Immunotherapy of acute myeloid leukemia: current approaches. Oncologist 2009, 14, 240-252. [CrossRef]

16. Barrett, A.J.; Le Blanc, K. Immunotherapy prospects for acute myeloid leukaemia. Clin. Exp. Immunol. 2010, 161, 223-232. [CrossRef]

17. Martner, A.; Thoren, F.B.; Aurelius, J.; Hellstrand, K. Immunotherapeutic strategies for relapse control in acute myeloid leukemia. Blood Rev. 2013, 27, 209-216. [CrossRef] [PubMed]

18. Tesfatsion, D.A. Dendritic cell vaccine against leukemia: advances and perspectives. Immunotherapy 2014, 6, 485-496. [CrossRef] [PubMed]

19. Pyzer, A.R.; Avigan, D.E.; Rosenblatt, J. Clinical trials of dendritic cell-based cancer vaccines in hematologic malignancies. Hum. Vaccin. Immunother. 2014, 10, 3125-3131. [CrossRef]

20. Rey, J.; Veuillen, C.; Vey, N.; Bouabdallah, R.; Olive, D. Natural killer and gamma delta T cells in haematological malignancies: enhancing the immune effectors. Trends Mol. Med. 2009, 15, 275-284. [CrossRef]

21. Hardy, M.Y.; Kassianos, A.J.; Vulink, A.; Wilkinson, R.; Jongbloed, S.L.; Hart, D.N.; Radford, K.J. NK cells enhance the induction of CTL responses by IL-15 monocyte-derived dendritic cells. Immunol. Cell Biol. 2009, 87, 606-614. [CrossRef]

22. Pampena, M.B.; Levy, E.M. Natural killer cells as helper cells in dendritic cell cancer vaccines. Front. Immunol. 2015, 6, 13. [CrossRef]

23. Chijioke, O.; Munz, C. Dendritic cell derived cytokines in human natural killer cell differentiation and activation. Front. Immunol. 2013, 4, 365. [CrossRef] [PubMed]

24. Lucas, M.; Schachterle, W.; Oberle, K.; Aichele, P.; Diefenbach, A. Dendritic cells prime natural killer cells by trans-presenting interleukin 15. Immunity 2007, 26, 503-517. [CrossRef] [PubMed]

25. Mortier, E.; Woo, T.; Advincula, R.; Gozalo, S.; Ma, A. IL-15Ralpha chaperones IL-15 to stable dendritic cell membrane complexes that activate NK cells via trans presentation. J. Exp. Med. 2008, 205, 1213-1225. [CrossRef] [PubMed]

26. Anguille, S.; Willemen, Y.; Lion, E.; Smits, E.L.; Berneman, Z.N. Dendritic cell vaccination in acute myeloid leukemia. Cytotherapy 2012, 14, 647-656. [CrossRef]

27. Van de Velde, A.L.; Beutels, P.; Smits, E.L.; Van Tendeloo, V.F.; Nijs, G.; Anguille, S.; Verlinden, A.; Gadisseur, A.P.; Schroyens, W.A.; Dom, S.; et al. Medical costs of treatment and survival of patients with acute myeloid leukemia in Belgium. Leuk. Res. 2016, 46, 26-29. [CrossRef] [PubMed]

28. van de Loosdrecht, A.A.; van Wetering, S.; Santegoets, S.; Singh, S.K.; Eeltink, C.M.; den Hartog, Y.; Koppes, M.; Kaspers, J.; Ossenkoppele, G.J.; Kruisbeek, A.M.; et al. A novel allogeneic off-the-shelf dendritic cell vaccine for post-remission treatment of elderly patients with acute myeloid leukemia. Cancer Immunol. Immunother. 2018, 67, 1505-1518. [CrossRef] [PubMed]

29. Draube, A.; Beyer, M.; Wolf, J. Activation of autologous leukemia-specific T cells in acute myeloid leukemia: monocyte-derived dendritic cells cocultured with leukemic blasts compared with leukemia-derived dendritic cells. Eur. J. Haematol. 2008, 81, 281-288. [CrossRef]

30. Houtenbos, I.; Westers, T.M.; Dijkhuis, A.; de Gruijl, T.D.; Ossenkoppele, G.J.; van de Loosdrecht, A.A. Leukemia-specific T-cell reactivity induced by leukemic dendritic cells is augmented by 4-1BB targeting. Clin. Cancer Res.: Off. J. Am. Assoc. Cancer Res. 2007, 13, 307-315. [CrossRef] [PubMed]

31. Curti, A.; Pandolfi, S.; Valzasina, B.; Aluigi, M.; Isidori, A.; Ferri, E.; Salvestrini, V.; Bonanno, G.; Rutella, S.; Durelli, I.; et al. Modulation of tryptophan catabolism by human leukemic cells results in the conversion of CD25- into CD25+ T regulatory cells. Blood 2007, 109, 2871-2877. [CrossRef]

32. Kitawaki, T.; Kadowaki, N.; Kondo, T.; Ishikawa, T.; Ichinohe, T.; Teramukai, S.; Fukushima, M.; Kasai, Y.; Maekawa, T.; Uchiyama, T. Potential of dendritic-cell immunotherapy for relapse after allogeneic 
hematopoietic stem cell transplantation, shown by WT1 peptide- and keyhole-limpet-hemocyanin-pulsed, donor-derived dendritic-cell vaccine for acute myeloid leukemia. Am. J. Hematol. 2008, 83, 315-317. [CrossRef]

33. Kitawaki, T.; Kadowaki, N.; Fukunaga, K.; Kasai, Y.; Maekawa, T.; Ohmori, K.; Kondo, T.; Maekawa, R.; Takahara, M.; Nieda, M.; et al. A phase I/IIa clinical trial of immunotherapy for elderly patients with acute myeloid leukaemia using dendritic cells co-pulsed with WT1 peptide and zoledronate. Br. J. Haematol. 2011, 153, 796-799. [CrossRef]

34. Shah, N.N.; Loeb, D.M.; Khuu, H.; Stroncek, D.; Ariyo, T.; Raffeld, M.; Delbrook, C.; Mackall, C.L.; Wayne, A.S.; Fry, T.J. Induction of Immune Response after Allogeneic Wilms' Tumor 1 Dendritic Cell Vaccination and Donor Lymphocyte Infusion in Patients with Hematologic Malignancies and Post-Transplantation Relapse. Biol. Blood Marrow Transpl. 2016, 22, 2149-2154. [CrossRef] [PubMed]

35. Ota, S.; Ogasawara, M. Vaccination of acute leukemia patients with WT1 peptide-pulsed dendritic cells induces immunological and clinical responses: a pilot study. Blood 2014, 124, 2319.

36. Ogasawara, M.; Ota, S. Dendritic cell vaccination in acute leukemia patients induces reduction of myeloid-derived suppressor cells: immunological analysis of a pilot study. Blood 2014, 124, 1113.

37. Fujii, S.; Shimizu, K.; Fujimoto, K.; Kiyokawa, T.; Tsukamoto, A.; Sanada, I.; Kawano, F. Treatment of post-transplanted, relapsed patients with hematological malignancies by infusion of HLA-matched, allogeneic-dendritic cells (DCs) pulsed with irradiated tumor cells and primed T cells. Leuk. Lymphoma 2001, 42, 357-369. [CrossRef]

38. Lee, J.J.; Kook, H.; Park, M.S.; Nam, J.H.; Choi, B.H.; Song, W.H.; Park, K.S.; Lee, I.K.; Chung, I.J.; Hwang, T.J.; et al. Immunotherapy using autologous monocyte-derived dendritic cells pulsed with leukemic cell lysates for acute myeloid leukemia relapse after autologous peripheral blood stem cell transplantation. J. Clin. Apher. 2004, 19, 66-70. [CrossRef] [PubMed]

39. Kitawaki, T.; Kadowaki, N.; Fukunaga, K.; Kasai, Y.; Maekawa, T.; Ohmori, K.; Itoh, T.; Shimizu, A.; Kuzushima, K.; Kondo, T.; et al. Cross-priming of CD8(+) T cells in vivo by dendritic cells pulsed with autologous apoptotic leukemic cells in immunotherapy for elderly patients with acute myeloid leukemia. Exp. Hematol. 2011, 39, 424-433. [CrossRef]

40. Chevallier, P.; Saiagh, S.; Dehame, V.; Guillaume, T.; Peterlin, P.; Garnier, A.; Le Bris, Y.; Bercegeay, S.; Coulais, D.; Rambaud, M.A.; et al. A Phase I/II Study of Vaccination By Autologous Leukemic Apoptotic Corpse Pulsed Dendritic Cells for Elderly Acute Myeloid Leukemia Patients in First or Second Complete Remission (LAM DC trial). Blood 2016, 128, 2821.

41. Massumoto, C.; Sousa-Canavez, J.M.; Leite, K.R.; Camara-Lopes, L.H. Stabilization of acute myeloid leukemia with a dendritic cell vaccine. Hematol. Oncol. Stem Cell 2008, 1, 239-240. [CrossRef]

42. Rosenblatt, J.; Stone, R.M.; Uhl, L.; Neuberg, D.; Joyce, R.; Levine, J.D.; Arnason, J.; McMasters, M.; Luptakova, K.; Jain, S.; et al. Individualized vaccination of AML patients in remission is associated with induction of antileukemia immunity and prolonged remissions. Sci. Transl. Med. 2016, 8, 368ra171. [CrossRef] [PubMed]

43. Bigalke, I.; Fløisand, Y.; Solum, G.; Hønnåshagen, K.; Lundby, M.; Anderson, K.; Sæbøe-Larssen, S.; Inderberg, E.-M.; Eckl, J.; Schendel, D.J.; et al. AML Patients in Minimal Residual Disease Vaccinated with a Novel Generation of Fast Dendritic Cells Expressing WT-1 and PRAME Mount Specific Immune Responses That Relate to Clinical Outcome. Blood 2015, 126, 3798.

44. Lichtenegger, F.S.; Deiser, K.; Rothe, M.; Schnorfeil, F.M.; Krupka, C.; Augsberger, C.; Kohnke, T.; Bucklein, V.L.; Altmann, T.; Moosmann, A.; et al. Induction of Antigen-Specific T-Cell Responses through Dendritic Cell Vaccination in AML: Results of a Phase I/II Trial and Ex Vivo Enhancement By Checkpoint Blockade. Blood 2016, 128, 5.

45. Khoury, H.J.; Collins, R.H., Jr.; Blum, W.; Stiff, P.S.; Elias, L.; Lebkowski, J.S.; Reddy, A.; Nishimoto, K.P.; Sen, D.; Wirth, E.D., 3rd; et al. Immune responses and long-term disease recurrence status after telomerase-based dendritic cell immunotherapy in patients with acute myeloid leukemia. Cancer 2017, 123, 3061-3072. [CrossRef]

46. Wang, D.H.; Huang, X.F.; Hong, B.X.; Song, X.T.; Hu, L.D.; Jiang, M.; Zhang, B.; Ning, H.M.; Li, Y.H.; Xu, C.; et al. Efficacy of intracellular immune checkpoint-silenced DC vaccine. JCI Insight 2018, 3. [CrossRef]

47. Ho, V.T.; Kim, H.T.; Kao, G.; Cutler, C.; Levine, J.; Rosenblatt, J.; Joyce, R.; Antin, J.H.; Soiffer, R.J.; Ritz, J.; et al. Sequential infusion of donor-derived dendritic cells with donor lymphocyte infusion for relapsed 
hematologic cancers after allogeneic hematopoietic stem cell transplantation. Am. J. Hematol. 2014, 89, 1092-1096. [CrossRef]

48. Li, L.; Giannopoulos, K.; Reinhardt, P.; Tabarkiewicz, J.; Schmitt, A.; Greiner, J.; Rolinski, J.; Hus, I.; Dmoszynska, A.; Wiesneth, M.; et al. Immunotherapy for patients with acute myeloid leukemia using autologous dendritic cells generated from leukemic blasts. Int. J. Oncol. 2006, 28, 855-861. [CrossRef] [PubMed]

49. Dong, M.; Liang, D.; Li, Y.; Kong, D.; Kang, P.; Li, K.; Ping, C.; Zhang, Y.; Zhou, X.; Zhang, Y.; et al. Autologous dendritic cells combined with cytokine-induced killer cells synergize low-dose chemotherapy in elderly patients with acute myeloid leukaemia. J. Int. Med Res. 2012, 40, 1265-1274. [CrossRef] [PubMed]

50. Przespolewski, A.; Szeles, A.; Wang, E.S. Advances in immunotherapy for acute myeloid leukemia. Future Oncol. (Lond. Engl.) 2018, 14, 963-978. [CrossRef]

51. Roddie, H.; Klammer, M.; Thomas, C.; Thomson, R.; Atkinson, A.; Sproul, A.; Waterfall, M.; Samuel, K.; Yin, J.; Johnson, P.; et al. Phase I/II study of vaccination with dendritic-like leukaemia cells for the immunotherapy of acute myeloid leukaemia. Br. J. Haematol. 2006, 133, 152-157. [CrossRef]

52. Van Tendeloo, V.F.; Van de Velde, A.; Van Driessche, A.; Cools, N.; Anguille, S.; Ladell, K.; Gostick, E.; Vermeulen, K.; Pieters, K.; Nijs, G.; et al. Induction of complete and molecular remissions in acute myeloid leukemia by Wilms' tumor 1 antigen-targeted dendritic cell vaccination. Proc. Natl. Acad. Sci. USA 2010, 107, 13824-13829. [CrossRef]

53. de Gruijl, T.D.; Santegoets, S.; van Wetering, S.; Singh, S.K.; Hall, A.; van den Loosdrecht, A.A.; Kruisbeek, A.M. Allogeneic dendritic cell (DC) vaccination as an "off the shelf" treatment to prevent or delay relapse in elderly acute myeloid leukemia patients: Results of phase I/IIa safety and feasibility study. J. Immunother. Cancer 2013, 1, P205. [CrossRef]

54. Mellor, A.L.; Lemos, H.; Huang, L. Indoleamine 2,3-Dioxygenase and Tolerance: Where Are We Now? Front. Immunol. 2017, 8, 1360. [CrossRef]

55. Chamuleau, M.E.; van de Loosdrecht, A.A.; Hess, C.J.; Janssen, J.J.; Zevenbergen, A.; Delwel, R.; Valk, P.J.; Lowenberg, B.; Ossenkoppele, G.J. High INDO (indoleamine 2,3-dioxygenase) mRNA level in blasts of acute myeloid leukemic patients predicts poor clinical outcome. Haematologica 2008, 93, 1894-1898. [CrossRef] [PubMed]

56. Folgiero, V.; Goffredo, B.M.; Filippini, P.; Masetti, R.; Bonanno, G.; Caruso, R.; Bertaina, V.; Mastronuzzi, A.; Gaspari, S.; Zecca, M.; et al. Indoleamine 2,3-dioxygenase 1 (IDO1) activity in leukemia blasts correlates with poor outcome in childhood acute myeloid leukemia. Oncotarget 2014, 5, 2052-2064. [CrossRef] [PubMed]

57. Mangaonkar, A.; Mondal, A.K.; Fulzule, S.; Pundkar, C.; Park, E.J.; Jillella, A.; Kota, V.; Xu, H.; Savage, N.M.; Shi, H.; et al. A novel immunohistochemical score to predict early mortality in acute myeloid leukemia patients based on indoleamine 2,3 dioxygenase expression. Sci. Rep. 2017, 7, 12892. [CrossRef]

58. Berneman, Z.N.; Van de Velde, A.L.; Willemen, Y.; Anguille, S.; Saevels, K.; Germonpré, P.; Huizing, M.T.; Peeters, M.; Snoeckx, A.; Parizel, P.; et al. Vaccination with WT1 mRNA-electroporated dendritic cells: report of clinical outcome in 66 cancer patients. Blood 2014, 124, 310.

59. Rosenblatt, J.; Stone, R.M.; Uhl, L.; Neuberg, D.; Vasir, B.; Somaiya, P.; Joyce, R.; Levine, J.D.; Boussiotis, V.A.; Zwicker, J.; et al. Clinical trial evaluating DC/AML fusion cell vaccination in AML patients who achieve a chemotherapy-induced remission. Biol. Blood Marrow Transpl. 2014, 20, S50. [CrossRef]

60. DiPersio, J.F.; Collins, R.H., Jr.; Blum, W.; Devetten, M.P.; Stiff, P.; Elias, L.; Reddy, A.; Smith, J.A.; Khoury, H.J. Immune Responses in AML Patients Following Vaccination with GRNVAC1, Autologous RNA Transfected Dendritic Cells Expressing Telomerase Catalytic Subunit hTERT. Blood 2009, 114, 262.

61. Khoury, H.J.; Collins, R.H., Jr.; Blum, W.; Maness, L.; Stiff, P.; Kelsey, S.M.; Reddy, A.; Smith, J.A.; DiPersio, J.F. Prolonged administration of the telomerase vaccine GRNVAC1 is well tolerated and appears to be associated with favorable outcomes in high-risk acute myeloid leukemia (AML). Blood 2010, 116, 904.

62. Teague, R.M.; Kline, J. Immune evasion in acute myeloid leukemia: current concepts and future directions. J. Immunother. Cancer 2013, 1, 13. [CrossRef]

63. Bai, X.F.; Liu, J.; Li, O.; Zheng, P.; Liu, Y. Antigenic drift as a mechanism for tumor evasion of destruction by cytolytic T lymphocytes. J. Clin. Invest. 2003, 111, 1487-1496. [CrossRef] [PubMed]

64. Anguille, S.; Van Tendeloo, V.F.; Berneman, Z.N. Leukemia-associated antigens and their relevance to the immunotherapy of acute myeloid leukemia. Leukemia 2012, 26, 2186-2196. [CrossRef] 
65. Melenhorst, J.J.; Scheinberg, P.; Chattopadhyay, P.K.; Gostick, E.; Ladell, K.; Roederer, M.; Hensel, N.F.; Douek, D.C.; Barrett, A.J.; Price, D.A. High avidity myeloid leukemia-associated antigen-specific CD8(+) T cells preferentially reside in the bone marrow. Blood 2009, 113, 2238-2244. [CrossRef]

66. Gulley, J.L.; Madan, R.A.; Schlom, J. Impact of tumour volume on the potential efficacy of therapeutic vaccines. Curr. Oncol. (Tor. Ont.) 2011, 18, e150-e157. [CrossRef]

67. Anguille, S.; Smits, E.L.; Lion, E.; van Tendeloo, V.F.; Berneman, Z.N. Clinical use of dendritic cells for cancer therapy. Lancet Oncol 2014, 15, e257-e267. [CrossRef]

68. Pawlowska, A.B.; Hashino, S.; McKenna, H.; Weigel, B.J.; Taylor, P.A.; Blazar, B.R. In vitro tumor-pulsed or in vivo Flt3 ligand-generated dendritic cells provide protection against acute myelogenous leukemia in nontransplanted or syngeneic bone marrow-transplanted mice. Blood 2001, 97, 1474-1482. [CrossRef]

69. Menssen, H.D.; Siehl, J.M.; Thiel, E. Wilms tumor gene (WT1) expression as a panleukemic marker. Int. J. Hematol. 2002, 76, 103-109. [CrossRef] [PubMed]

70. Trka, J.; Kalinova, M.; Hrusak, O.; Zuna, J.; Krejci, O.; Madzo, J.; Sedlacek, P.; Vavra, V.; Michalova, K.; Jarosova, M.; et al. Real-time quantitative PCR detection of WT1 gene expression in children with AML: prognostic significance, correlation with disease status and residual disease detection by flow cytometry. Leukemia 2002, 16, 1381-1389. [CrossRef] [PubMed]

71. Ogawa, H.; Tamaki, H.; Ikegame, K.; Soma, T.; Kawakami, M.; Tsuboi, A.; Kim, E.H.; Hosen, N.; Murakami, M.; Fujioka, T.; et al. The usefulness of monitoring WT1 gene transcripts for the prediction and management of relapse following allogeneic stem cell transplantation in acute type leukemia. Blood 2003, 101, 1698-1704. [CrossRef] [PubMed]

72. Garg, M.; Moore, H.; Tobal, K.; Liu Yin, J.A. Prognostic significance of quantitative analysis of WT1 gene transcripts by competitive reverse transcription polymerase chain reaction in acute leukaemia. Br. J. Haematol. 2003, 123, 49-59. [CrossRef] [PubMed]

73. Cilloni, D.; Renneville, A.; Hermitte, F.; Hills, R.K.; Daly, S.; Jovanovic, J.V.; Gottardi, E.; Fava, M.; Schnittger, S.; Weiss, T.; et al. Real-time quantitative polymerase chain reaction detection of minimal residual disease by standardized WT1 assay to enhance risk stratification in acute myeloid leukemia: a European LeukemiaNet study. J. Clin. Oncol. Off. J. Am. Soc. Clin. Oncol. 2009, 27, 5195-5201. [CrossRef] [PubMed]

74. Widen, K.; Mozaffari, F.; Choudhury, A.; Mellstedt, H. Overcoming immunosuppressive mechanisms. Ann. Oncol. Off. J. Eur. Soc. Med Oncol. / Esmo 2008, 19, vii241-vii247. [CrossRef]

75. Farag, S.S.; Maharry, K.; Zhang, M.J.; Perez, W.S.; George, S.L.; Mrozek, K.; DiPersio, J.; Bunjes, D.W.; Marcucci, G.; Baer, M.R.; et al. Comparison of reduced-intensity hematopoietic cell transplantation with chemotherapy in patients age 60-70 years with acute myelogenous leukemia in first remission. Biol. Blood Marrow Transpl. 2011, 17, 1796-1803. [CrossRef] [PubMed]

76. Byrd, J.C.; Mrozek, K.; Dodge, R.K.; Carroll, A.J.; Edwards, C.G.; Arthur, D.C.; Pettenati, M.J.; Patil, S.R.; Rao, K.W.; Watson, M.S.; et al. Pretreatment cytogenetic abnormalities are predictive of induction success, cumulative incidence of relapse, and overall survival in adult patients with de novo acute myeloid leukemia: results from Cancer and Leukemia Group B (CALGB 8461). Blood 2002, 100, 4325-4336. [CrossRef] [PubMed]

77. Lion, E.; Willemen, Y.; Berneman, Z.N.; Van Tendeloo, V.F.I.; Smits, E.L.J. Natural killer cell immune escape in acute myeloid leukemia. Leukemia 2012, 26, 2019-2026. [CrossRef] [PubMed]

78. Lion, E.; Smits, E.L.; Berneman, Z.N.; Van Tendeloo, V.F. NK cells: key to success of DC-based cancer vaccines? Oncologist 2012, 17, 1256-1270. [CrossRef] [PubMed]

79. Van Acker, H.H.; Anguille, S.; Van Tendeloo, V.F.; Lion, E. Empowering gamma delta T cells with antitumor immunity by dendritic cell-based immunotherapy. Oncoimmunology 2015, 4, e1021538. [CrossRef]

80. van Beek, J.J.; Gorris, M.A.; Skold, A.E.; Hatipoglu, I.; Van Acker, H.H.; Smits, E.L.; de Vries, I.J.; Bakdash, G. Human blood myeloid and plasmacytoid dendritic cells cross activate each other and synergize in inducing NK cell cytotoxicity. Oncoimmunology 2016, 5, e1227902. [CrossRef] [PubMed]

81. Van Acker, H.H.; Beretta, O.; Anguille, S.; De Caluwe, L.; Papagna, A.; Van den Bergh, J.M.; Willemen, Y.; Goossens, H.; Berneman, Z.N.; Van Tendeloo, V.F.; et al. Desirable cytolytic immune effector cell recruitment by interleukin-15 dendritic cells. Oncotarget 2017, 8, 13652-13665. [CrossRef]

82. Van Acker, H.H.; Anguille, S.; De Reu, H.; Berneman, Z.N.; Smits, E.L.; Van Tendeloo, V.F. Interleukin-15-Cultured Dendritic Cells Enhance Anti-Tumor Gamma Delta T Cell Functions through IL-15 Secretion. Front. Immunol. 2018, 9, 658. [CrossRef] 
83. van Ee, T.J.; Van Acker, H.H.; van Oorschot, T.G.; Van Tendeloo, V.F.; Smits, E.L.; Bakdash, G.; Schreibelt, G.; de Vries, I.J.M. BDCA1+CD14+ Immunosuppressive Cells in Cancer, a Potential Target? Vaccines (Basel) 2018, 6, 65. [CrossRef] [PubMed]

84. Ueno, H.; Schmitt, N.; Klechevsky, E.; Pedroza-Gonzalez, A.; Matsui, T.; Zurawski, G.; Oh, S.; Fay, J.; Pascual, V.; Banchereau, J.; et al. Harnessing human dendritic cell subsets for medicine. Immunol. Rev. 2010, 234, 199-212. [CrossRef] [PubMed]

85. Palucka, K.; Banchereau, J. Cancer immunotherapy via dendritic cells. Nat. Rev. Cancer 2012, $12,265-277$. [CrossRef]

86. Curti, A.; Trabanelli, S.; Onofri, C.; Aluigi, M.; Salvestrini, V.; Ocadlikova, D.; Evangelisti, C.; Rutella, S.; De Cristofaro, R.; Ottaviani, E.; et al. Indoleamine 2,3-dioxygenase-expressing leukemic dendritic cells impair a leukemia-specific immune response by inducing potent $\mathrm{T}$ regulatory cells. Haematologica 2010, 95, 2022-2030. [CrossRef]

87. Anguille, S.; Lion, E.; Smits, E.; Berneman, Z.N.; van Tendeloo, V.F.I. Dendritic cell vaccine therapy for acute myeloid leukemia: questions and answers. Hum. Vaccines 2011, 7, 579-584. [CrossRef]

88. Anguille, S.; Smits, E.L.; Cools, N.; Goossens, H.; Berneman, Z.N.; Van Tendeloo, V.F. Short-term cultured, interleukin-15 differentiated dendritic cells have potent immunostimulatory properties. J. Transl. Med. 2009, 7, 109. [CrossRef] [PubMed]

89. Anguille, S.; Lion, E.; Tel, J.; de Vries, I.J.; Coudere, K.; Fromm, P.D.; Van Tendeloo, V.F.; Smits, E.L.; Berneman, Z.N. Interleukin-15-induced CD56(+) myeloid dendritic cells combine potent tumor antigen presentation with direct tumoricidal potential. Plos ONE 2012, 7, e51851. [CrossRef]

90. Anguille, S.; Van Acker, H.H.; Van den Bergh, J.; Willemen, Y.; Goossens, H.; Van Tendeloo, V.F.; Smits, E.L.; Berneman, Z.N.; Lion, E. Interleukin-15 Dendritic Cells Harness NK Cell Cytotoxic Effector Function in a Contact- and IL-15-Dependent Manner. PLoS ONE 2015, 10, e0123340. [CrossRef]

91. Versteven, M.; Van den Bergh, J.M.J.; Marcq, E.; Smits, E.L.J.; Van Tendeloo, V.F.I.; Hobo, W.; Lion, E. Dendritic Cells and Programmed Death-1 Blockade: A Joint Venture to Combat Cancer. Front. Immunol. 2018, 9, 394. [CrossRef]

92. Giannopoulos, K. Targeting Immune Signaling Checkpoints in Acute Myeloid Leukemia. J. Clin. Med. 2019, 8, 236. [CrossRef]

93. Masarova, L.; Kantarjian, H.; Garcia-Mannero, G.; Ravandi, F.; Sharma, P.; Daver, N. Harnessing the Immune System Against Leukemia: Monoclonal Antibodies and Checkpoint Strategies for AML. Adv. Exp. Med. Biol. 2017, 995, 73-95.

94. Liu, Y.; Bewersdorf, J.P.; Stahl, M.; Zeidan, A.M. Immunotherapy in acute myeloid leukemia and myelodysplastic syndromes: The dawn of a new era? Blood Rev. 2019, 34, 67-83. [CrossRef]

95. Lee, S.C.; Srivastava, R.M.; Lopez-Albaitero, A.; Ferrone, S.; Ferris, R.L. Natural killer (NK): dendritic cell (DC) cross talk induced by therapeutic monoclonal antibody triggers tumor antigen-specific $\mathrm{T}$ cell immunity. Immunol. Res. 2011, 50, 248-254. [CrossRef] [PubMed]

96. Gribben, J.G.; Ryan, D.P.; Boyajian, R.; Urban, R.G.; Hedley, M.L.; Beach, K.; Nealon, P.; Matulonis, U.; Campos, S.; Gilligan, T.D.; et al. Unexpected association between induction of immunity to the universal tumor antigen CYP1B1 and response to next therapy. Clin. Cancer Res. Off. J. Am. Assoc. Cancer Res. 2005, 11, 4430-4436. [CrossRef]

97. Nahas, M.R.; Stroopinsky, D.; Rosenblatt, J.; Cole, L.; Pyzer, A.R.; Anastasiadou, E.; Sergeeva, A.; Ephraim, A.; Washington, A.; Orr, S.; et al. Hypomethylating agent alters the immune microenvironment in acute myeloid leukaemia (AML) and enhances the immunogenicity of a dendritic cell/AML vaccine. Br. J. Haematol. 2019. [CrossRef]

(C) 2019 by the authors. Licensee MDPI, Basel, Switzerland. This article is an open access article distributed under the terms and conditions of the Creative Commons Attribution (CC BY) license (http://creativecommons.org/licenses/by/4.0/). 